\title{
Calcinosis as a complication of juvenile dermatomyositis (JDM)
}

\author{
Malagón Clara*, Yépez Ricardo, Contreras Luz \\ From 18th Pediatric Rheumatology European Society (PReS) Congress \\ Bruges, Belgium. 14-18 September 2011
}

\section{Background}

Calcinosis is a common complication of JDM. It may varies on extension and severity. May cause mechanical and aesthetic complications and predispose to infections.

\section{Aim}

To evaluate the frequency and features of calcinosis in a cohort of patients with JDM and identify if there are risk factors.

\section{Methods}

Retrospective descriptive study in 3 pediatric rheumatology centers in Bogota during a period of 20 years. Two groups were identified according to the presence or absence of clinical and radiological signs of calcinosis after a minimum of 2 years of follow up.

\section{Results}

17/42 developed calcinosis associated with earlier onset of the disease, male predominance and chronic. Calcium

Table

\begin{tabular}{|c|c|c|c|c|c|}
\hline GROUP & \multicolumn{2}{|c|}{$\begin{array}{l}\text { With } \\
\text { calcinosis }\end{array}$} & \multicolumn{2}{|c|}{$\begin{array}{l}\text { Without } \\
\text { calcinosis }\end{array}$} & Pvalue \\
\hline Number & \multicolumn{2}{|l|}{17} & \multicolumn{2}{|l|}{25} & \\
\hline Sex distribution (Male:female) & \multicolumn{2}{|l|}{ 1.83:1 } & \multicolumn{2}{|l|}{$1: 3.16$} & 0,008 \\
\hline Age of onset (average of years) & \multicolumn{2}{|c|}{$6,29(1,5-12)$} & \multicolumn{2}{|c|}{$7,08(2-16)$} & 0,633 \\
\hline Delayed diagnosis (>6months) & $6 / 17$ & $35 \%$ & $5 / 25$ & $20 \%$ & 0,268 \\
\hline Monocyclic & $1 / 17$ & $6 \%$ & $12 / 25$ & $48 \%$ & 0,004 \\
\hline Policiclic & $3 / 17$ & $18 \%$ & $3 / 25$ & $12 \%$ & 0,608 \\
\hline Chronic & $14 / 17$ & $82 \%$ & $7 / 25$ & $28 \%$ & 0,001 \\
\hline
\end{tabular}

* Correspondence: claramalagonmd@gmail.com

Pediatric Rheumatology fellowship program, Faculty of Medicine,

Universidad el Bosque, Bogotá, Colombia deposits were classified as: superficial nodular, deep nodular, mass, linear or mixed deposits and calcinosis universalis. $80 \%$ had two or more types of deposits. The anatomical areas more frequently affected were the thighs and forearms. Complications included: drainage, chronic ulcers, mass effect, mechanical blockage of the joints and infections. Severe calcinosis was also associated with significant muscle atrophy loss and lipodystrophy.

\section{Conclusion}

Calcinosis is common and severe of JDM. It leads to various complications and treatment response is poor. Early diagnosis and proper treatment may reduce the frequency of this complication.

Published: 14 September 2011

\section{doi:10.1186/1546-0096-9-S1-P55 \\ Cite this article as: Clara et al:: Calcinosis as a complication of juvenile dermatomyositis (JDM). Pediatric Rheumatology 2011 9(Suppl 1):P55.}

Submit your next manuscript to BioMed Central and take full advantage of:

- Convenient online submission

- Thorough peer review

- No space constraints or color figure charges

- Immediate publication on acceptance

- Inclusion in PubMed, CAS, Scopus and Google Scholar

- Research which is freely available for redistribution

Submit your manuscript at www.biomedcentral.com/submit

\section{() Biomed Central}

